\title{
Communicative Approach to Foreign Language Teaching
}

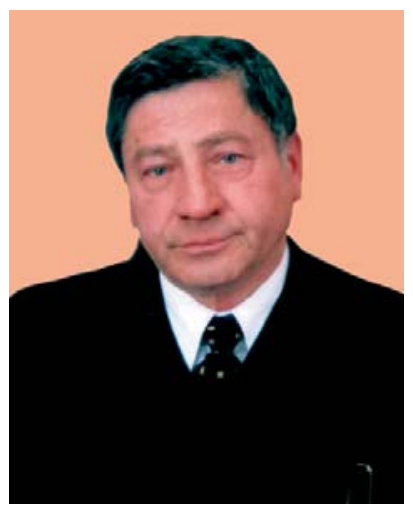

Karo Karapetyan

T $\mathrm{t}$ is a well-known fact that communicative language teaching began in Britain in the 1960s, in part as a replacement for the earlier, highly-structured method of situational language teaching. Up to now CL learning/teaching is one of the basic approaches practical teachers or applied linguists try to follow in the language classroom in its pure or modified version to achieve better result. Attention has been focused on the importance of using materials of a more authentic nature in the language classroom. This need is interpreted as informal conversational discourse, and in this case a new set of difficulties are likely to arise, most of them relating to the fact that this material can only be inauthentically used in the foreign language classroom.

A thorough study of principal propositions and the necessity to survey, synthesize, as well as to examine the relevance of various areas of inquiry will help to define the communicative method as one of the most productive and reliable approaches to language teaching. In the language materials it is very important to trace and to analyze the influence of sociolinguistic factors and then discuss in greater detail some of the more recent developments in the theory of communicative language teaching.

More narrowly-focused teacher dominated notional-functional perspectives are contrasted with more broadly-defined discourse-processing viewpoints, in which teaching is constructed around the process competence of the learner. It is suggested that broader perspectives are likely to encounter interpretive difficulty, since they require a radical departure from existing methodologies.

Employing the broadest perspectives, most commentators who have contributed to the current communicative approach debate, would probably agree that teaching and learning English communicatively involves using the language for particular purposes in tasks and activities which evoke a strong sense of relevance to the learner's interests (White, 1980).

It should be pointed out that our understanding of the term refers not only to principles of syllabus design, but also to the presentation of classroom teaching materials and the methodology that underlies them. This approach differs from those, which limit their interpretations to the principles of syllabus design (White, 1980, Wilkins, 1978).

Similarly, few would disagree, that historically, the main contribution to the theory of communicative language teaching/learning was the impetus afforded by sociolinguistic and sociosemantic factors in the late 60-s and throughout the 70-s. Among other contributions the cognitive theories of language teaching/learning should be mentioned. 
Campbell and Wales in 1970 were certainly among the first to argue that Chomsky's definition of competence (1965) was inadequate as it failed to refer to performance phenomena and to the sociocultural factors of appropriateness to the context in which language was used. Hymes took up the argument, saying that a child would be likely to be institutionalized. We have then to account for the fact that a common child acquires knowledge of sentences, not only as grammatically correct but also as appropriate. He or she acquires competence as to when to speak, when not, and as to what to talk about with whom, when, where, and in what manner. In other words, a child becomes able to accomplish a repertoire of speech acts, to take part in speech events, and to evaluate the accomplishments of others. This competence, moreover, is integral with attitudes, values and motivations concerning language... (Hymes, 1972, pp. 277-278).

Thus, it has been suggested that there are rules of use without which the rules of grammar would be useless. In addition to commenting on the interaction of grammatical, psycholinguistic, sociocultural and probabilistic aspects of situated language use, Hymes also considered (1967) the formulation of rules of language use by analyzing speech events in terms of their constituents or components. These he identified as: participants, setting, scene (psychocultural setting), message form, and message content, purpose, key, channel, code, norms of interaction, norms of interpretation and genre. However, there has been little conclusive research into the way in which these factors systematically interact, Hymes himself has pointed out that all of these components may not always be crucial in all speech events - their categorization and clarification thus has been of considerable benefit to language teachers, working on syllabus specifications in terms of providing a framework for the series of questions that need to be asked in identifying parameters of relevance.

Halliday (1973) discussed the interrelation of language and social context and provided a set of behavioural options which are realized as sets of semantic options, which, in turn, are realized as sets of grammatical options. The influence of other sociolinguists and discourse analysts is more noticeably apparent in their more detailed discussion of discoursal sequencing and rhetorical language use, thus relating to Hyme's more general definition of communication skills, as outlined above.

In seeking a pedagogic application of the Hallidayan view of factors accounting for communicative competence, some authors (e.g. Canal and Swain, 1980; Munly, 1978) doubt whether grammatical competence can or should be developed from the standpoint of meaning at the very beginning of a second or Foreign Language Learning programme, arguing that it may be more realistic to view the normal process at the beginning of such learning as one, in which what can be said (grammatical options) determines, in some way, what can be meant (semantic options) in the second language. Nonetheless, it is quite possible that at later stages of second language learning, grammatical options are more of a direct realization of semantic options rather than the reverse. It is recognized that the communicative use of language from the earliest stage will possibly facilitate this development.

Fillmore, for instance, in discussing the question of coherent discourse within a theory of conversation and the varied relationship between form and function, provides 
us with numerous pertinent examples of use as far as the rhetorical rules of language are concerned. In fact we can imagine contexts in which the sequence "Thank you - You are welcome" is inappropriate. Consider a three-line conversation in which A says "You have lovely eyes", B says " Thank you " and A then says "You are welcome ". The sequence can be an interpretation, of course, but we recognize it as bizarre by realizing that the function of "You are welcome" is partly that of expressing acknowledgment.

H.Widdowson, in his discussion of cohesion seen as linking propositional development and coherence seen as linking illocutionary development, suggests that these relationships are discovered by the reader/listener as a result of practical reasoning in his interpretation of the discourse. Textual and discourse processing factors are seen as one important aspect of the reading process in much of the discussion that follows (Widdowson, 1978).

In this short and summarizing overview, however, our concern is not giving an exhaustive description of the contributions sociolinguistics and sociosemantics have made to communicative language teaching/learning. Our main task here is to set down the areas of inquiry, commonly accepted among applied linguists as contributing to the study of discourse and communicative syllabus development. I have so far indicated what I believe to be areas of agreement concerning the background and definition of communicative learning-teaching, but such agreement, as we have found, does not extend to more detailed definitions of the process. Using language for particular purposes, strong sense of relevance to the learner's interests describes communicative language teaching/learning only in the most general terms. If we attempt to focus more clearly and attempt to probe the essential characteristics in some detail, we shall encounter a very broad spectrum of definition.

At one end of this spectrum lies the functional \notional definition of communicative teaching/learning as applied to syllabuses primarily concerned with development of oral (mainly production) skills in general English and reflected in a substantial number of course books.

H.Widdowson's words remind us of the importance of discourse and of the ability to process discourse in any genuinely communicative approach:

"If we are to adapt a communicative approach to teaching which takes as its primary purpose the development of the ability to do things with language, then it is discourse which must be the center of our attention. There are two basic characteristics of discourse which we need to account for. The first is that it is essentially interactive, and involves the negotiation of meanings. The second characteristic is that this interaction creates hierarchical structures whereby the combination of propositions and illocutions builds up to a larger unit of communication”. (Widdowson,1977).

The task of practical teachers is to translate the theoretical framework of the language into a practical application as communication is a process of relating language forms and language behaviour in the context of social events. It is necessary to stress that the conventions that link forms and behaviour are not fixed for all time, nor certain among different participants in an event or across events they are variable and need to be constantly negotiated and accepted. Communication becomes a convention creating rather than a merely convention-following activity. It is a social and interpersonal process. Learning to communicate is, as a result, not a 
matter of digesting a static and predictable body of knowledge, but learning how to interpret, express and negotiate through and about these conventions.

\section{References:}

1. White R.V. Teaching Written English. London, Allen and Unwin, 1980.

2. Wilkins D.A. Notional Syllabuses. Oxford, Oxford University Press, 1978.

3. Campbell R., Wales R. The Study of Language Acquisition. In: Lyons J. New Horizons in Linguistics. Cambridge, Cambridge University Press, 1970.

4. Chomsky N. Aspects of the Theory of Syntax. Cambridge, Mass., M.I.T. Press, 1965.

5. Hymes D. On Communicative Competence. In: Sociolinguistics ed.by Pride J.B., Holmes J. Philadelphia, Penguin, 1972.

6. Halliday M.A.K. Explorations in the Functions of Language. London, Edward Arnold, 1973.

7. Canale M., Swain M. Theoratical Bases of Communicative Approaches to Second Language Teaching and Testing. In: Applied Linguistics, 1980, v.1

8. Munby J. Communicative Syllabus Design. Cambridge, Cambridge University Press, 1978.

9. Fillmore C. A Grammarian Looks to Sociolinguistics. In: Sociolinguistic Aspect of Language Learning and Teaching ed. by Pride J.B. Oxford, Oxford University Press, 1979.

10. Widdowson H.G. The Communicative Approach and its Application ed. by Widdowson H.G., Oxford, Oxford University Press, 1979.

11. Widdowson H.G. Exploration in Applied Linguistics. Oxford, Oxford University Press, 1979.

12. Widdowson H.G. Teaching Language as Communication. Oxford, Oxford University Press, 1996.

\section{Zunnnnulygulqu氏 únuntignıu ounup stiqnılitph nıunıgưuan}

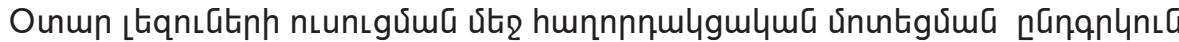

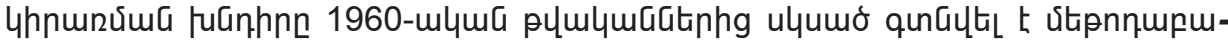

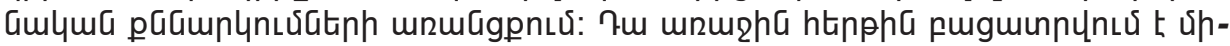

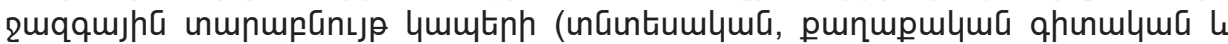
mJLG) mlyunhy qunqugưurup:

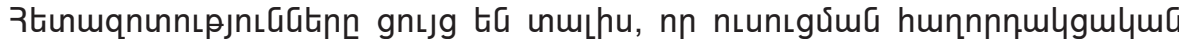

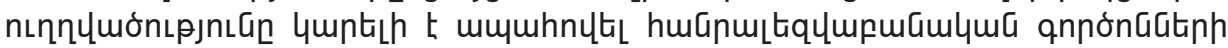

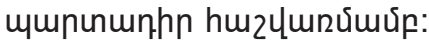

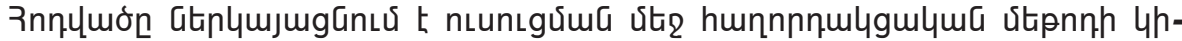
nunर्umG unupptip ưnuntigntưGtin: 